\title{
sciendo
}

\section{DIFFERENCES IN BIOACTIVE PROTEIN AND VITAMIN STATUS OF MILK OBTAINED FROM POLISH LOCAL BREEDS OF COWS*}

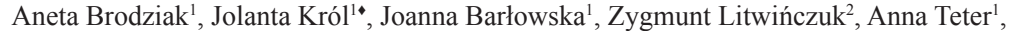 \\ Monika Kędzierska-Matysek ${ }^{3}$ \\ ${ }^{1}$ Institute of Quality Assessment and Processing of Animal Products, Sub-Department of Food Safety \\ and Regional Products \\ ${ }^{2}$ Institute of Animal Breeding and Biodiversity Conservation, Sub-Department of Cattle Breeding \\ and Genetic Resources Conservation \\ ${ }^{3}$ Institute of Quality Assessment and Processing of Animal Products, Sub-Department of Instrumental \\ Food Analysis \\ Faculty of Animal Sciences and Bioeconomy, University of Life Sciences in Lublin, \\ Akademicka 13, 20-950 Lublin, Poland \\ •Corresponding author: jolanta.krol@up.lublin.pl
}

\begin{abstract}
The aim of the study was to compare the content of selected bioactive whey proteins and lipophilic vitamins, which largely determine the bioactive status of milk, in milk obtained from local breeds of cows raised in Poland (Polish Red, White-Backed and Simmental) and Polish Holstein-Friesian cows. Basic chemical composition and content of selected bioactive compounds ( $\beta$-lactoglobulin, $\alpha$-lactalbumin, lactoferrin, bovine serum albumin, and vitamins: $E, A, D_{3}$ and $\beta$-carotene) in 550 milk samples were analysed. The milk produced by local breeds proved to be a more valuable source of whey proteins and lipophilic vitamins than that of the Polish Holstein-Friesians. It was distinguished by its content of all bioactive compounds, including those with antioxidant properties, i.e. vitamins $E, A$ and $D_{3}$ and $\beta$-lactoglobulin, and antimicrobial properties, mainly lactoferrin. Therefore, the milk of cows of local breeds should be considered a valuable material for processing, especially at the level of the farm or small local processing plant, to produce products that are richer in health-promoting compounds. The promotion of milk from local breeds can therefore be an opportunity for the farms that raise them.
\end{abstract}

Key words: local breeds, milk, whey proteins, lipophilic vitamins

An increasing number of farms raising dairy cows are introducing intensive milk production systems, i.e. replacing tie-stall barns with free-stall barns (building new ones or modernizing old ones), in which the same complete feed ration system

*The research was carried out under the project: "The uses and the conservation of farm animal genetic resources under sustainable development" co-financed by the National Centre for Research and Development within the framework of the strategic R\&D programme "Environment, agriculture and forestry" - BIOSTRATEG, contract number: BIOSTRATEG2/297267/14/NCBR/2016. 
(TMR - Total Mixed Ration or PMR - Partial Mixed Ration) is used year round (Litwińczuk et al., 2014). A small number of transboundary breeds, predominantly Holstein-Friesian, are used in these systems. An alternative is traditional milk production systems, which are usually used on low-input family farms. These farms are most often located in regions with hard temperate natural conditions (e.g. mountains, foothills or wetlands). In these areas the use of native (local) breeds is preferred because they adapt easily to the unfavourable environment. Animals of these breeds are also more resistant to disease, including mastitis, and are distinguished by longevity and calving ease (Litwińczuk et al., 2012). There are 1,224 cattle breeds registered in the world, and the vast majority of them $(83 \%)$ are local breeds. It should be noted that 184 of these are classified as extinct, and 171 are threatened with extinction (FAO, 2016). In Poland, there are four native cattle breeds (Polish Red, White-Backed, Polish Black-and-White and Polish Red-and-White), which due to the threat of extinction are covered by a genetic resources conservation programme implemented by the National Research Institute of Animal Production in Balice.

Cows of native breeds, unfortunately, are less productive as compared to the breeds used in intensive production systems (Gandini et al., 2007). However, research by many authors (Bergamo et al., 2003; Butler et al., 2008; Król et al., 2010; Litwińczuk et al., 2012; Ramalho et al., 2012; Petrera et al., 2016; Puppel et al., 2017) indicates that their milk is of higher nutritional value and more suitable for processing than milk produced in intensive systems. This is mainly due to the fodder obtained from permanent grassland forming the basis of the cows' diet on low-input farms, especially in spring and summer (Collomb et al., 2008; Król et al., 2011; Kuczyńska et al., 2011; Gabryszuk et al., 2013; Brodziak et al., 2018). In some countries, including Italy, Spain and Portugal, native breeds have been promoted for many years by using their milk to produce regional products. This is also a response to public demand, because increasing numbers of consumers are looking for regional food, which they associate with greater nutritional value, a lack of additives, and health benefits (Annunziata and Vecchio, 2016; Balogh et al., 2016; Feldmann and Hamm, 2014; Grunert and Aachmann, 2016). It should be emphasized that the available Polish and foreign literature contains few studies devoted to the content of nutrients with a high bioactive status in milk obtained from indigenous cows (Król et al., 2010; Litwińczuk et al., 2012; Petrera et al., 2016). This is particularly true of vitamins (Pires et al., 2003; Ramalho et al., 2012).

Hence the aim of the study was to compare the content of selected bioactive whey proteins and lipophilic vitamins, which largely determine the bioactive status of milk, in milk obtained from local breeds of cows raised in Poland and Polish Holstein-Friesian cows.

\section{Material and methods}

\section{Research material}

The study was conducted on milk obtained on 18 traditional family farms raising local breeds of cattle (Polish Red, White-Backed and Simmental), located in 
south-eastern Poland, i.e. in the Lublin region, Podlasie, the Bieszczady Mountains, and the Low Beskids. Due to the large share of permanent grassland in these areas, a traditional milk production system is used. The cows' diet in the spring and summer is based on pasture with the addition of hay and cereal meal, while in the autumn and winter they receive haylage supplemented with hay and cereal meal (Table 1). The Polish Black-and-White Holstein-Friesian cows were raised in an intensive system. Their diet throughout the year was based on a PMR (partial mixed ration) system, in which the feed ration consists of bulky feed (maize silage and haylage) and concentrate feeds.

Table 1. Characteristics of farms covered by research

\begin{tabular}{|c|c|c|}
\hline Specification & Conventional & Intensive (PMR system) \\
\hline Number of farms & 18 & 2 \\
\hline $\begin{array}{l}\text { Average number of cows } \\
\text { in a herd }\end{array}$ & $12(10-20)$ & 60 \\
\hline $\begin{array}{l}\text { Average daily milk yield } \\
\text { per cow }(\mathrm{kg})\end{array}$ & 15.1 & 26.8 \\
\hline \multirow[t]{2}{*}{ Feeding of cows } & $\begin{array}{l}\text { Summer season: } \\
\text { pasture }- \text { ad libitum } \\
\text { hay }-3 \mathrm{~kg} \\
\text { grain meal }-2 \mathrm{~kg}\end{array}$ & $\begin{array}{l}\text { Summer season: } \\
\text { haylage + maize silage - approx. } 35 \mathrm{~kg} \\
\text { meal }-2-3 \mathrm{~kg}\end{array}$ \\
\hline & $\begin{array}{l}\text { Winter season: } \\
\text { haylage - approx. } 20 \mathrm{~kg} \\
\text { hay }-3 \mathrm{~kg} \\
\text { grain meal }-2-3 \mathrm{~kg}\end{array}$ & $\begin{array}{l}\text { Winter season: } \\
\text { haylage }+ \text { maize silage - approx. } 35 \mathrm{~kg} \\
\text { meal }-4-5 \mathrm{~kg}\end{array}$ \\
\hline Milking system & \multicolumn{2}{|c|}{ Bucket or pipeline milking system Milking parlour } \\
\hline Animal housing & Tied & Free-stall barns \\
\hline
\end{tabular}

Milk samples were collected in 2016-2018, individually from each cow during test-day milking, in two production seasons, i.e. spring/summer (May-June) and autumn/winter (December-January). Cows selected for the study were in the middle period (between 30 and 120 days) of lactation. An effort was made to collect milk from the same cows. In total, 550 milk samples were collected from local breeds, including 172 from Polish Red, 188 from White-Backed, and 190 from Simmentals, and 128 samples were collected from Polish Holstein-Friesians. All milk samples (with a volume of $250 \mathrm{ml}$ ) taken to the plastic containers were transported to the laboratory (AOAC, 2000).

\section{Analysis of samples}

Basic chemical composition, i.e. solids, protein, fat and lactose content by Infrared Milk Analyzer (Bentley Instruments, USA), casein content (according to AOAC, 2000) and somatic cell count - SCC (by Somacount 150; Bentley Instruments) were analysed. Determination of the content of biologically active compounds, i.e. selected whey proteins and vitamins, was carried out only in milk samples in which 
SCC did not exceed 400,000 cells in $1 \mathrm{ml}$ of milk (Commission Regulation no 1662/2006).

In order to evaluate the content of certain whey proteins, i.e. $\alpha$-lactalbumin $(\alpha$-LA), $\beta$-lactglobulin ( $\beta$-LG), lactoferrin and bovine albumin serum (BSA), RPHPLC method was used. All samples were prepared according to Romero et al. (1996) with modifications (Brodziak et al., 2012). Protein separation was performed on liquid chromatograph ProStar 210 model and UV-VIS ProStar 325 detector (Varian, USA). The measurements were carried out using the water/acetonitrile mobile phase at gradient elution and column Nucleosil 300-5 C18 (ProStar Varian, USA) of $250 \mathrm{~mm}$ length and $4.6 \mathrm{~mm}$ diameter. The mobile phase was solvent A (90\% water, $10 \%$ acetonitrile) and solvent B (90\% acetonitrile, $10 \%$ water), purchased from Sigma-Aldrich (Germany). The total analysis time for a single sample was $35 \mathrm{~min}$ at $205 \mathrm{~nm}$ wavelength with column temperature of $37^{\circ} \mathrm{C}$. The analyses of reference substances were conducted under the same conditions. Purified proteins, i.e. $\alpha$-LA ( $\geq 85 \%)$, $\beta$-LG $(90 \%)$, bovine albumin serum ( $\geq 96 \%)$ and lactoferrin $(90 \%)$ all from bovine milk, as well lysozyme $(95 \%)$ from hen egg whites, were purchased from Sigma-Aldrich (Germany). On the grounds of the obtained chromatograms, using program Star 6.2 Chromatography Workstation (Varian, USA), the qualitative and quantitative identification of each substance was performed followed by their concentration determination. Calibration of the chromatographic system for whey proteins determination was carried out by the external standard method.

RP-HPLC method was also used to determine the concentrations of fat-soluble vitamins, i.e. $\mathrm{A}, \mathrm{D}_{3}$ and $\mathrm{E}$, and $\beta$-carotene. All samples were prepared by the RöseGottlieb fat extraction method as modified by Hewavitharana et al. (1996). Vitamin separation was performed by a liquid chromatograph ProStar 210 model, a UV-VIS ProStar 325 and fluorescence ProStar 363 detectors (Varian, USA). Mobile phase was a mixture of acetonitrile, dichloromethane, methanol and water for HPLC (SigmaAldrich, Germany), and the flow rate was set at $1 \mathrm{ml} / \mathrm{min}$. The measurements were carried out using the column Pursuit XRs 3-C18 (Varian, USA) of $150 \mathrm{~mm}$ length and $4.6 \mathrm{~mm}$ diameter. The analyses of reference substances, i.e. $( \pm)$ - $\alpha$-tocopherol $\left(\geq 97 \%\right.$ HPLC) for vitamin $\mathrm{E}$, cholecalciferol ( $\geq 98 \%$ HPLC) for vitamin $\mathrm{D}_{3}$, retinol ( $\geq 99 \%$ HPLC) for vitamin A and $\beta$-carotene ( $\geq 95 \%$ HPLC) (Sigma-Aldrich, Germany), were conducted under the same conditions. On the grounds of the obtained chromatograms, the qualitative identification of each substance was performed, using Star 6.2 Chromatography Workstation (Varian, USA).

\section{Statistical analysis}

Statistical analysis of the results was performed in StatSoft Inc. Statistica 13.1 software (Dell, 2016) using one- and two-way analysis of variance with interaction. Significance of differences between means for individual parameters were determined by the Tukey's test at significance levels of $\mathrm{P}<0.05$ and $\mathrm{P}<0.01$. Results were presented as mean $\pm \mathrm{SD}$. 


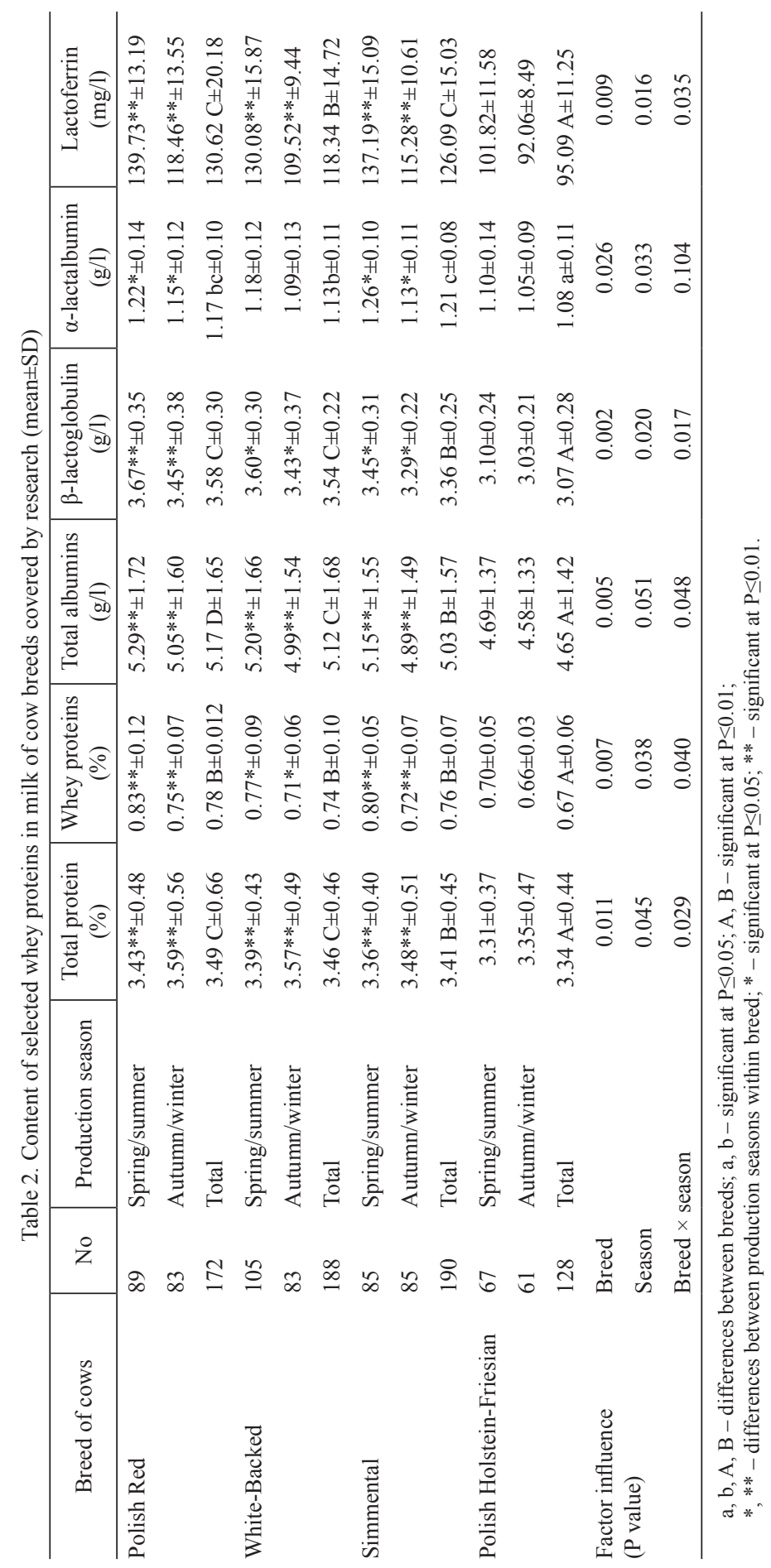




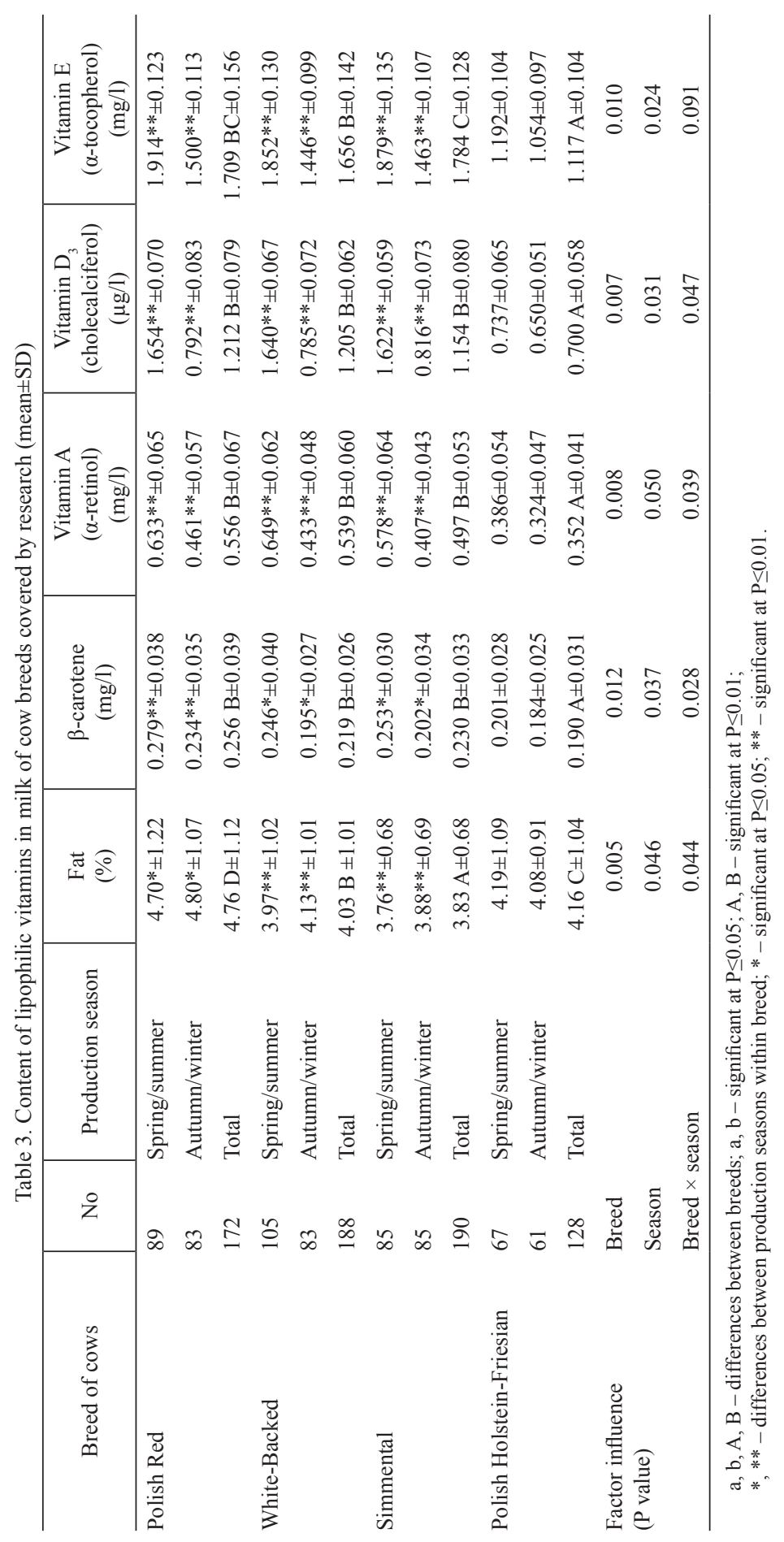




\section{Results}

The results indicate that both the breed and the production season had a significant effect on the quantity of the milk constituents (Tables 2 and 3). The milk of Holstein-Friesian Polish cows, which are the most important breed in milk production in Poland and around the world, had the lowest content of total protein $(3.34 \pm 0.44 \%)$, including whey proteins $(0.67 \pm 0.06 \%)$, and the lowest share of whey proteins in the total protein $(19.6 \pm 0.85 \%$; Table 2$)$. The milk of local breeds contained between 0.07 (Simmental) and $0.15 \mathrm{pp}$. (Polish Red) more total protein, including whey proteins (from 0.07 to $0.11 \mathrm{pp}$.). The share of these proteins ranged from $21.3 \%$ (Simmental) to $22.5 \%$ (Polish Red). Most of the whey proteins (about $70 \%$ ) were albumins, i.e. $\beta$-lactoglobulin and $\alpha$-lactalbumin. Their content proved to be significantly highest in the milk produced by local breeds; the milk of Polish Red cows was the richest source of albumins, including $\beta$-lactoglobulin $(5.17 \pm 1.65$ and $3.58 \pm 0.30 \mathrm{~g} / \mathrm{l}$, respectively), and Simmental milk was the best source of $\alpha$-lactalbumin $(1.21 \pm 0.08 \mathrm{~g} / \mathrm{l})$. The milk of the Polish Holstein-Friesian cows contained on average $0.46 \mathrm{~g} / \mathrm{l}$ less albumin, $0.42 \mathrm{~g} / 1$ less $\beta$-lactoglobulin and $0.09 \mathrm{~g} / 1$ less $\alpha$-lactalbumin. The research also showed that the milk of cows of local breeds had significantly $(\mathrm{P} \leq 0.01)$ higher content of lactoferrin (on average 24\%) than that of Polish Holstein-Friesians. The most lactoferrin was found in the milk of Polish Red cows $(130.62 \pm 20.18 \mathrm{mg} / \mathrm{l})$ and Simmental cows $(126.09 \pm 15.03 \mathrm{mg} / \mathrm{l})$.

Our research indicates that the milk with the most $\beta$-lactoglobulin also had the highest levels of vitamins $\mathrm{A}$ and $\mathrm{D}_{3}$ (Table 3 ). That was also confirmed by obtained high correlation coefficients between the content of $\beta$-lactoglobulin and vitamin $\mathrm{A}-$ $\mathrm{r}=0.702(\mathrm{P}<0.01)$ and between $\beta$-lactoglobulin and vitamin $\mathrm{D}_{3}-\mathrm{r}=0.584(\mathrm{P}<0.01)$ in analysed milk. The milk of Polish Red cows was the most valuable in this respect (vitamin A $-0.556 \pm 0.067 \mathrm{mg} / \mathrm{l}$; vitamin $\mathrm{D}_{3}-1.212 \pm 0.079 \mu \mathrm{g} / \mathrm{l}$ ). Significantly the lowest content of vitamins $\mathrm{A}_{\text {and }} \mathrm{D}_{3}$ was noted in the milk with the lowest concentration of $\beta$-LG, i.e. the milk of Polish Holstein-Friesian cows. The milk of local breeds also proved to be more valuable source of other vitamins, i.e. $\mathrm{E}$ and $\beta$-carotene. Hence the milk obtained from cows of local breeds contained significantly more lipophilic vitamins, i.e. $\beta$-carotene (on average by about $20 \%$ ), vitamins $\mathrm{A}$ and $\mathrm{E}$ $(50 \%)$ and vitamin $\mathrm{D}_{3}(70 \%)$ than the milk of Holstein-Friesian cows.

Seasonal differences were also shown in the content of the constituents of milk obtained from local breeds. Significantly higher content of total protein was found in the autumn/winter season and of whey protein in the spring/summer season, when the animals used the pasture. In the milk obtained in the summer, there was also an increase in the content of all analysed lipophilic vitamins, in particular that of vitamin $\mathrm{D}_{3}$, which was twice as high. Seasonal differences for other vitamins were $20 \%$ for $\beta$-carotene, $25 \%$ for vitamin $\mathrm{E}$, and $50 \%$ for vitamin A (Table 3 ). However, the production season was not found to affect the content of these constituents in the milk of Holstein-Friesian cows, which can be explained by the uniform diet used year round. 


\section{Discussion}

The content of whey proteins and vitamins is one indicator of the health-promoting quality of milk. Due to their numerous health-promoting properties, whey proteins, especially lactoferrin, are increasingly raising interest, and in recent years they have been widely used in a number of industries, including the food, pharmaceutical and cosmetics industries (Król et al., 2011; Bruni et al., 2016; Giansanti et al., 2016). Our research showed that milk from local breeds is a richer source of whey proteins, both total and individual, than milk obtained from Polish Holstein-Friesian cows. The results are supported by previous research of team (Król et al., 2010; Litwińczuk et al., 2012), as well as studies by other authors (Collomb et al., 2008; Kuczyńska et al., 2012; Claesson, 2016). On the other hand, Wedholm et al. (2006), who studied the milk of two Swedish breeds of cows (Red-and-White and Holstein), did not find that the breed influenced the concentration of whey proteins. The content of the proteins analysed was also determined by the production season, with higher content noted during the grazing period, as reported in other research (Król et al., 2008; Puppel et al., 2017; Brodziak et al., 2018). The content of certain components of the protein fraction is closely linked to the amount of fat-soluble vitamins. According to Dolores-Perez and Calvo (1994), the concentration of $\beta$-lactoglobulin is positively correlated with the content of vitamin A, because this protein actively participates in the transport of small hydrophobic molecules such as $\alpha$-retinol. Bulgari et al. (2013) indicated a relationship between genetic polymorphism of $\beta$-lactoglobulin and the amount of vitamin D in milk. The AA genotype of $\beta$-lactoglobulin was associated with significantly $(\mathrm{P} \leq 0.01)$ higher content of vitamin $\mathrm{D}_{3}$. Our research confirmed that the milk containing the most $\beta$-lactoglobulin also had the highest content of vitamins $A$ and $D_{3}$. Kuczyńska et al. (2011) also confirmed the relationship between the content of vitamin $A$ and $\beta-L G$ in milk. The milk of local breeds also proved to be the most valuable source of other vitamins, i.e. vitamin $E$ and $\beta$-carotene. Brodziak et al. (2018) obtained relatively high correlation coefficients between the content of $\beta$-carotene and vitamin $\mathrm{E}-\mathrm{r}=0.432(\mathrm{P}<0.05)$ and between $\beta$-carotene and vitamin $\mathrm{A}-\mathrm{r}=0.502(\mathrm{P}<0.05)$ in the milk of Simmental cows. It is worth noting that $\beta$-carotene plays the role of a vitamin A precursor, which is why their concentrations are closely linked. The presence of vitamin A in milk is important due to its role in vision and reproduction, as well as in the differentiation, growth and development of cells (Debier et al., 2005; Jin et al., 2014). Retinol and its forms together with vitamin $\mathrm{D}_{3}$ are found only in raw material and products of animal origin. They are much better absorbed in their natural forms than in synthetic forms.

The results of our research indicated that the milk obtained from local breeds of cows had a higher bioactive status than Holstein-Friesian milk. This is supported by studies carried out on the milk of cows of local breeds raised in Portugal (Minhota and Barrosã) (Pires et al., 2003; Ramalho et al., 2012). Pires et al. (2003) compared the milk of Barrosã cows and Friesian cows and found twice as much vitamin D and $10 \%$ more vitamin A in the milk of the indigenous breed. Ramalho et al. (2012) reported that the milk of the Minhota breed had significantly higher levels of vitamins $\mathrm{A}$ and $\mathrm{E}$ and $\beta$-carotene. However, no breed-related differences were found in the 
content of vitamin $\mathrm{D}_{3}$. Radkowska (2013) found similar content of vitamins $\mathrm{A}$ and $\mathrm{E}$ in the milk of two groups of Polish Holstein-Friesian cows, where one remained in the cow barn at all times and the other had access to a cattle run. In contrast, pasturegrazed cows produced milk with significantly higher $(\mathrm{P} \leq 0.05)$ content of these vitamins. Many authors (Shingfield et al., 2005; Nozière et al., 2006) indicate that green pasture forage has higher levels of vitamin $\mathrm{E}$ and provitamin A than preserved fodders, and for this reason pasture feeding positively influences their content in milk. As grazing animals are exposed to UV rays, the amount of vitamin $\mathrm{D}_{3}$ increases as well (Bergamo et al., 2003; Butler et al., 2008; Kuczyńska et al., 2011; Gabryszuk et al., 2013). Our research also showed significant seasonal differences in favour of the spring/summer period, when the cows were in the pasture. These dependencies were observed in the milk from cows of local breeds. Hulshof et al. (2006) reported that cow milk obtained in the Netherlands during the summer and early autumn (July-October) contained significantly more retinol and $\beta$-carotene (by about 20\%) in comparison with winter and early spring (January-April). Strusińska et al. (2010) reported higher content of lipophilic vitamins in the milk of cows grazed in the pasture compared to that of cows fed TMR with maize silage. An increase in the content of lipophilic vitamins in the summer on extensive farms has also been confirmed in other studies (Lindmark-Månsson et al., 2003; Toledo and Andren, 2003; Agabriel et al., 2007). According to Chauveau-Duriot et al. (2005), reduced content of carotenoids in milk is associated with a high proportion of silage in the feed ration. This is due to the method of preservation of green fodder; for example, in sun-dried hay UV radiation causes the degradation of as much as $83 \%$ of carotenoids as compared to silage produced from fresh fodder. According to Agabriel et al. (2007), seasonal differences in the content of vitamin $\mathrm{E}$ and $\beta$-carotene in milk result from the share of pasture forage and grass silage in the feed ration.

To sum up, both the breed of cow and the production season significantly influenced the level of the analysed constituents of the protein and fat fractions, thus determining the bioactive status of the milk. The milk produced by local breeds proved to be a more valuable source of these substances than that of the Polish HolsteinFriesians. It was distinguished by its content of all bioactive compounds, including those with antioxidant properties, i.e. vitamins $\mathrm{E}, \mathrm{A}$ and $\mathrm{D}_{3}$ and $\beta$-lactoglobulin, and antimicrobial properties, mainly lactoferrin. Therefore, the milk of cows of local breeds should be considered a valuable material for processing, especially at the level of the farm or small local processing plant, to produce products that are richer in health-promoting compounds. The promotion of milk from local breeds can therefore be an opportunity for the farms that raise them.

\section{Acknowledgments}

Authors would like to thank Barbara Topyła, Ph.D., and Agnieszka Wawryniuk, M.Sc., for technical support of the research. 


\section{References}

A gabriel C., Cornu A., J ournal C., S ibra C., Groli er P., Mart in B. (2007). Tanker milk variability according to farm feeding practices: vitamins A and E, carotenoids, colour, and terpenoids. J. Dairy Sci., 90: 4884-4896.

Annunziata A., Vec ch i o R. (2016). Organic farming and sustainability in food choices: An analysis of consumer preference in Southern Italy. Agr. Agr. Sci. Procedia, 8: 193-200.

AOAC (2000). Official Methods of Analysis. 17th ed. AOAC International, Arlington, VA.

B a log h P., B é ké s i D., G or to n M., P o p p J., L e n g y e 1 P. (2016). Consumer willingness to pay for traditional food products. Food Policy, 61: 176-184.

B ergamo P., Fedele E., I annibelli L., Marzillo G. (2003). Fat-soluble vitamin contents and fatty acid composition in organic and conventional Italian dairy product. Food Chem., 82: 625-631.

Brodziak A., Barłowska J., Król J., Litwińczuk Z. (2012). Effect of breed and feeding system on content of selected whey proteins in cows' milk in spring-summer and autumn-winter seasons. Ann. Anim. Sci., 12: 261-269.

Brodziak A., Król J., Litwiń c zuk Z., B arłowska J. (2018). Differences in bioactive protein and vitamin status of milk from certified organic and conventional farms. Int. J. Dairy Technol., 71: 321-332.

Bruni N., Capucchio M.T., Biasibetti E., Pessione E., Cirrincione S., Giraudo L., C or on a A., D o s i o F. (2016). Antimicrobial activity of lactoferrin-related peptides and applications in human and veterinary medicine. Molecules, 21: 752.

B u lgari O., Caroli A.M., Ches s a S., Rizzi R., Gigli ot ti C.(2013). Variation of vitamin D in cow's milk and interaction with $\beta$-lactoglobulin. Molecules, 18: 10122-10131.

Butler G., Niels en J.H., Slots T., Seal C., Eyre M.D., S anderson R., Leifert C. (2008). Fatty acid and fat-soluble antioxidant concentrations in milk from high- and low-input conventional and organic systems: seasonal variation. J. Sci. Food Agric., 88: 1431-1441.

Chauveau-Duriot B., Thom a D., Portelli J., Doreau M. (2005). Carotenoids content in forages: Variation during conservation. Renc. Rech. Rumin., 12: 117.

C l a e s s o n C. (2016). Swedish native mountain cattle and their milk proteins: conventional compared to pasture operated farming for indoor and outdoor period. Independent Project in Food Science, Bachelor Project, Swedish University of Agricultural Sciences, Department of Food Science, Uppsala, no 451.

Collo mb M., B is ig W., Bütikofer U., S i eber R., Bregy M., Etter L. (2008). Seasonal variation in the fatty acid composition of milk supplied to dairies in the mountain regions of Switzerland. Dairy Sci. Technol., 88: 631-647.

Commission Regulation (EC) No 1662/2006 of 6 November 2006 amending Regulation (EC) No $853 / 2004$ of the European Parliament and of the Council laying down specific hygiene rules for food of animal origin (L 320).

D e bi er C., P otti e r J., G offe C., L a rondelle Y. (2005). Present knowledge and unexpected behaviours of vitamins A and E in colostrum and milk. Livest. Prod. Sci., 98: 135-147.

D o lore s- P e re z M., C a lv o M. (1994). Interaction of $\beta$-lactoglobulin with retinol and fatty acids and its role as a possible biological function for this protein: Review. J. Dairy Sci., 78: 978-988.

F e l d m a n n C., H a m m U. (2014). Consumers' perceptions and preferences for local food: A review. Food Qual. Prefer., 40: 152-164.

Gabryszuk M., S a k ow ski T., Metera E., Kuczyńska B., Re mbiałkow ska E. (2013). Effect of feeding on content of bioactive substances in milk from cows raised in organic farms (in Polish). Zywn.-Nauk. Technol. Ja., 88: 16-26.

Gandini G., Maltecca C., Pizzi F., Bagnato A., Rizzi R. (2007). Comparing local and commercial breeds on functional traits and profitability: the case of Reggiana dairy cattle. J. Dairy Sci., 90: 2004-2011.

Giansanti F., Panella G., Leboffe L., Antonini G. (2016). Lactoferrin from milk: nutraceutical and pharmacological properties. Pharmaceuticals, 9: 61.

Grunert K.G., A a c h m an n K. (2016). Consumer reactions to the use of EU quality labels on food products: A review of the literature. Food Control, 59: 178-187. 
Hew a vith ar a n A.K., v a n Brakel A.S., H a r n et t M. (1996). Simultaneous liquid chromatographic determination of vitamins A, E and beta-carotene in common dairy foods. Int. Dairy J., 6 : 613-624.

Hulshof P.J.M., van Roekel-Jansen T., van de Bovenkamp P., West C.E. (2006). Variation in retinol and carotenoid content of milk and milk products in the Netherlands. J. Food Compost. Anal., 19: 67-75.

Jin L., Yan S.M., Shi B.L., B a o H., Gong J., Gu o X., Li J. (2014). Effects of vitamin A on the milk performance, antioxidant functions and immune functions of dairy cows. Anim. Feed Sci. Technol., 192: 15-23.

Król J., Litwińczuk Z., Brodziak A. (2008). Content of protein and its fractions in milk of Simental cows with regard to a rearing technology. Ann. Anim. Sci., 1: 57-61.

Król J., Litwińczuk Z., B rodzi a k A., S a w i c ka-Z u gaj W. (2010). Bioactive protein content in milk from local breeds of cows included in the genetic resources conservation programme. Ann. Anim. Sci., 10: 213-221.

Kró 1 J., Brodziak A., Litwińczuk Z., S zwajkow s ka M. (2011). Whey protein utilization in health promotion (in Polish). Żyw. Człow. Metab., 38: 36-45.

Kuczyńska B., Nałęcz-Tarwacka T., Puppel K., Gołębiewski M., Grodzki H., S ló s a r z J. (2011). The content of bioactive components in milk depending on cow feeding model in certified ecological farms. J. Res. Appl. Agr. Eng., 56: 7-13.

Kuczyńska B., Puppel K., Gołębiewski M., Kordyasz M., Grodzki H., Brzoz o w s k i P. (2012). Comparison of fat and protein fractions of milk constituents in Montbeliarde and Polish Holstein-Friesian cows from one farm in Poland. Acta Vet. Brno, 81: 139-144.

Lindmark-Måns s on H., F onden R., Petters s o n H.E. (2003). Composition of Swedish dairy milk. Int. Dairy J., 13: 409-425.

Litw iń c zuk Z., B a rłow sk a J., Chabuz W., B rodzi a k A. (2012). The nutritional value and technological suitability of milk from cows of 3 Polish breeds included in the programme of genetic resources conservation. Ann. Anim. Sci., 12: 423-432.

L i t w iń c z u k Z., K ow a 1 M., B a rło w s k a J. (2014). Basic chemical composition, proportion of fatty acids, and cholesterol content in milk of four breeds of cows used in the intensive husbandry technologies (in Polish). Zywn.-Nauk. Technol. Ja., 95: 108-121.

Nozière P., Graulet B., Lucas A., Martin B., Grolier P., Doreau M. (2006). Carotenoids for ruminants: From forages to dairy products. Anim. Feed Sci. Technol., 131: $418-450$.

Petrera F., Catillo G., Napolitano F., Malacarne M., Franceschi P., Summer A., A b e n i F. (2016). New insights into the quality characteristics of milk from Modenese breed compared with Italian Friesian. Ital. J. Anim. Sci., 15: 559-567.

Pires P., Fernandes É., Vilarinho M., Barros M., Ferreira R., Carneiro L., A 1 m e i d a G., Vaz - Vel h o M.V. (2003). Comparison of milk from two different cow breeds Barrosã and Frísia. Electron. J. Environ. Agric. Food Chem., 2: 514-518.

Puppel K., Sakowski T., Kuczyńska B., Grodkowski G., Gołębiewski M., Barszczewski J., Wróbel B., Budziński A., Kapusta A., Balcerak M. (2017). Degrees of antioxidant protection: A 2-year study of the bioactive properties of organic milk in Poland. J. Food Sci., 82: 525-528.

R a d k ow s k a I. (2013). Effect of housing system and diet on the fatty acid, vitamin and macronutrient content of milk from Holstein-Friesian cows (in Polish). Scient. Ann. Pol. Soc. Anim. Prod., 40: $171-182$.

R a ma 1 ho H.M.M., S a n to s J., C a s a 1 S., A lve s M.R., O live ir a M.B.P.P. (2012). Fat-soluble vitamin (A, D, E, and $\beta$-carotene) contents from a Portuguese autochthonous cow breed - Minhota. J. Dairy Sci., 95: 5476-5484.

R o m e ro C., P erez - A n dú jar O., O 1 m e d o A., Ji m én ez S. (1996). Detection of cow's milk in ewe's or goat's milk by HPL. Chromatographia, 42: 181-184.

Shingfield K.J., Salo-Väänänen P., Pahkala E., Toivonen V., Jaakkola S., Piironen V., Huhtanen P. (2005). Effect of forage conservation method, concentrate level and propylene glycol on the fatty acid composition and vitamin content of cows' milk. J. Dairy Res., 72: 349-361. 
Strusińska D., Antoszkiewicz Z., Kaliniewicz J. (2010). The concentrations of $\beta$-carotene, vitamin $A$ and vitamin $E$ in bovine milk in regard to the feeding season and the share of concentrate in the feed ration. Scient. Ann. Pol. Soc. Anim. Prod., 6: 213-220.

To le d o P., A ndre n A. (2003). Content of beta carotene in organic milk. J. Food Agr. Environ., 2: $122-125$.

We dholm A., Hallén E., Lar se n L.B., Lind mark-Mån s s on H., Kar ls s on A.H., A 11 mer e T. (2006). Comparison of milk protein composition in a Swedish and a Danish dairy herd using reversed phase HPLC. Acta Agric. Scand. A Anim. Sci., 56: 8-15.

Received: 17 IV 2019

Accepted: 1 X 2019 